\title{
Evaluation of groundwater sustainability based on groundwater age simulation in the Zhangye Basin of Heihe River watershed, northwestern China
}

\author{
Heng WEI $I^{1,2^{*}}$, HongLang XIAO ${ }^{1}$, ZhenLiang $\mathrm{YIN}^{1,2}$, ZhiXiang $L U^{1,2}$ \\ ${ }^{1}$ Cold and Arid Regions Environmental and Engineering Research Institute, Chinese Academy of Sciences, Lanzhou 730000, China; \\ ${ }^{2}$ University of Chinese Academy of Sciences, Beijing 100049, China
}

\begin{abstract}
Water resources, as the primary limiting factor, constrain the economic and social development in arid inland areas. The Zhangye Basin is a representative area of inland river basins, which is located in the middle parts of the Heihe River watershed, northwestern China. Facing with the huge water shortage, people exploited groundwater at a large scale in recent years. The reducing recharge from surface water and over-exploitation of groundwater led to the decline of groundwater levels and threatened the sustainability of water resources. This study constructed a conceptual and numerical groundwater flow model and calibrated the model based on the observed wells. A solute transport model was built using MT3DMS to calculate the groundwater age distribution in the Zhangye Basin. The simulated result shows that the youngest groundwater is distributed near the most upstream areas in the model domain, which is less than $1,000 \mathrm{a}$, older groundwater is distributed in deeper parts of the aquifer and near the discharge outlets, ranging from 6,000 a to over 20,000 a. Spatial variation of groundwater ages in the middle area indicates the recharge diversity between unconfined and confined aquifer. Groundwater age can serve as an indicator to evaluate groundwater's renewal capacity and sustainability. The formation of groundwater resources in the lower stream area would spend 10,000 a or even more than 20,000 a, so exploitation of groundwater in these areas should be restrained.
\end{abstract}

Keywords: groundwater flow; groundwater age; numerical modeling; water resource sustainability

Citation: Heng WEI, HongLang XIAO, ZhenLiang YIN, ZhiXiang LU. 2014. Evaluation of groundwater sustainability based on groundwater age simulation in the Zhangye Basin of Heihe River watershed, northwestern China. Journal of Arid Land, 6(3): 264-272. doi: 10.1007/s40333-013-0210-y

Groundwater extraction has significantly facilitated social development and economic growth, but also depressed water table and degraded ecosystems in the fragile arid region. However, the fact that groundwater in some aquifer is renewed slowly is easy to ignore (Gleeson, 2010). And regional groundwater flow is complicated because of different hydrogeology conditions, varying land cover and land use, changing climate, human exploitation and many other factors. Physical-based numerical groundwater flow models almost became the only feasible method to study this issue because they can represent high spatial/temporal variability of the complicated factors listed above (Sophocleous and Perkins, 2000; Dafny et al., 2010; Peleg and Gvirtzman, 2010). These hydro-geologic groundwater flow models can provide water resources management suggestions by simulating the target region groundwater flow (Zhao et al., 2005; Chen et al., 2009; Xi et al., 2010; Luo and Sophocleous, 2011). The previous models work mostly focused on predicting groundwater level changes, which just represent the quality characteristics of water resources. In recent years, hydrologists began to use groundwater age to investigate the nature of subsurface flow re-

*Corresponding author: Heng WEI (E-mail: fening@163.com) 
gimes (Wilson et al., 2010; Vincent et al., 2013). Groundwater age can provide critical information in the hydrological cycle, e.g. recharge rate, renewal rate and residence time. By calculating the groundwater age in different aquifers, the recharge source will be identified, mixing process between different sources would be determined. Further, both the renewal rate and residence time inferred from groundwater age can be used as key indicator to evaluate the sustainable capacity of water resources.

Water is the most vital resource in arid and semi-arid region of northwestern China. Water scarcity limits the economical and agricultural development, brings about the vulnerable eco-system deterioration (Feng et al., 2002; Qian et al., 2006; Ma et al., 2012; Chen et al., 2013). The Zhangye Basin, in the middle part of the Heihe River watershed, is a representative region of northwestern China. Similar to other two basins of the three largest inland river basins in China, the Tarim and Shiyang River basins, Zhangye Basin is confronted with the eco-system deterioration in rapid social development. In the last 50 years, water resources in Zhangye Basin were over exploited under the pressure of rapid population growth and economical development. The overexploitation of water has caused a series of environmental problems, such as groundwater drawdown, wetland shrinking, land desertification and ecology degradation ( $\mathrm{Lu}$ and Cheng, 2003; Wang et al. 2007). Many researches urge to solve above conflict between economic development and environment sustainability. The fields of these researches involve ecology, hydrology, agriculture, and especially groundwater. However, water resources sustainability evaluation based on groundwater age has not been reported yet.

MODFLOW (Modular Three-Dimensional Groundwater Flow Model) is one of the most widely used groundwater models (Anderson and Woessner, 1992). MT3DMS (Multispecies Transport 3-Dimensional Model Supplement) is considered to be the most successful model in solute transport simulating field. This study developed the three dimensional groundwater flow and transport model based on MODFLOW and MT3DMS, to simulate the distributed groundwater level, and calculate groundwater age in the Zhangye Basin. The groundwater sustainability was evaluated from the model results and the suggestions about water resources management were proposed in this study. This result may provide a new way to research the groundwater in northwestern China, such as the Tarim River and Shiyang River basins.

\section{Study area and methods}

\subsection{Study area}

The Heihe River is the second largest inland river in China. It originates from the Qilian Mountains, flowing through the Qinghai and Gansu provinces, terminating in the Ejina Basin of the Inner Mongolia autonomous region with a total length of $821 \mathrm{~km}$. The Heihe River flows mainly from the southeast to the northwest in the Zhangye Basin.

The Zhangye Basin is located in the midstream region of the Heihe River (Fig. 1). The basin (38 $46^{\prime} 16^{\prime \prime}$ to $39^{\circ} 46^{\prime} 21^{\prime \prime} \mathrm{N}, 9^{\circ} 9^{\prime} 39^{\prime \prime}$ to $100^{\circ} 43^{\prime} 11^{\prime \prime} \mathrm{E}$ ) has the elevation ranging from $1,514.7-1,254.8 \mathrm{~m}$. It covers an area of $5.476 \times 10^{3} \mathrm{~km}^{2}$, including Zhangye city, Linze county and Gaotai county.

The climate of the Zhangye Basin is continental with a long dry season from October to May in the next year and a rainy season from June to September. The minimum, maximum and annual temperatures are $-31.0^{\circ} \mathrm{C}, 39.1^{\circ} \mathrm{C}$ and $7.4^{\circ} \mathrm{C}$, respectively. Average annual precipitation is $115.6 \mathrm{~mm}$ and average annual evaporation is $2,107.1 \mathrm{~mm}$.

The Zhangye Basin is an independent hydro geologic unit with a complete recharge-flow-discharge process (Wen et al., 2007). The basin is characterized by the uplifts of Alashan and Qilian mountains rounded northern and southern, and the uplifts of Yumu Mountain around western. The basin is filled with unconsolidated Quaternary sediments with a depth of hundreds of meters, which provide good conditions for groundwater storage. The aquifer system in Zhangye Basin can be classified by single unconfined aquifer and multilayer unconfined-confined aquifer (Ding and Zhang, 2002). The single unconfined aquifer locates in the upstream of Zhangye Basin, where is the piedmont alluvial plain. This aquifer is 


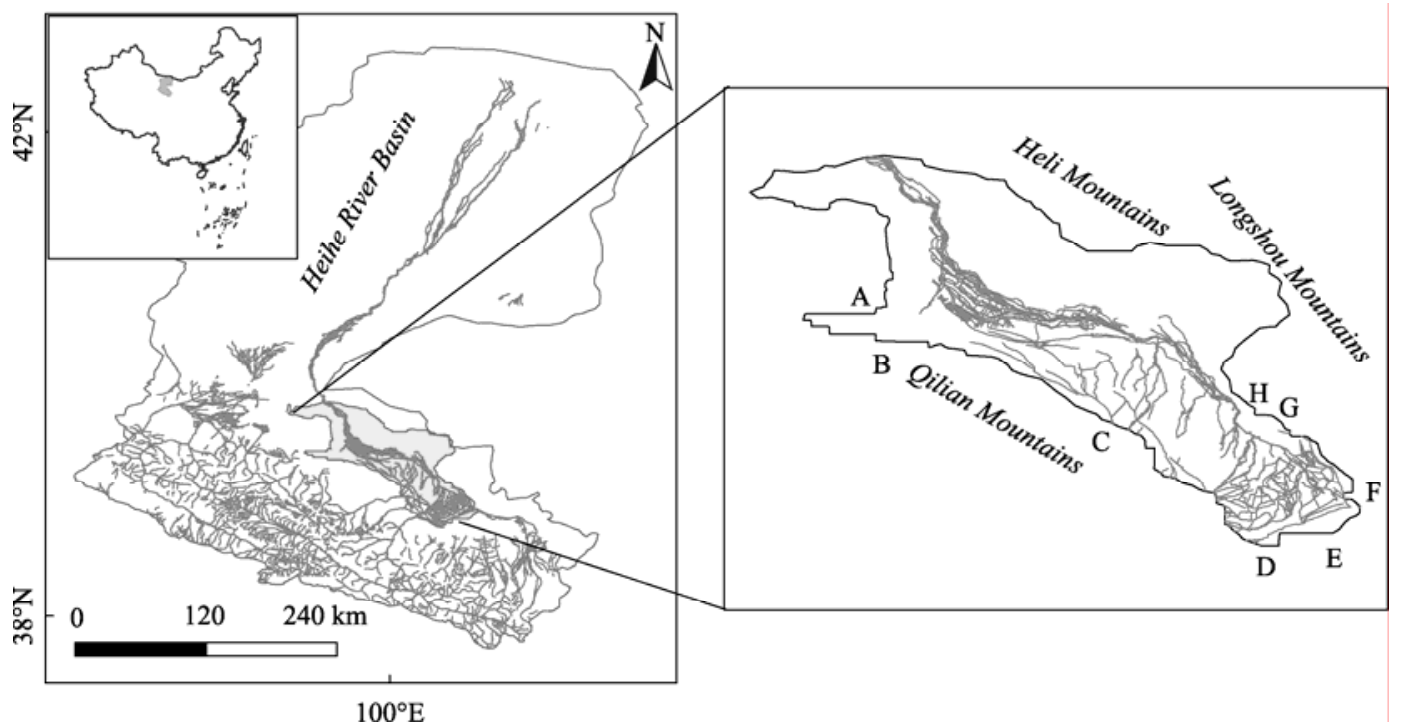

Fig. 1 The location of the Zhangye Basin in Heihe River; A, B, C, D, E, F, G, H marked boundary conditions in Section 1.3.3.

mainly composed of uniform gravel and cobble, with a fine permeability of hydraulic conductivity up to $30-50 \mathrm{~m} / \mathrm{d}$. The multilayer unconfined-confined aquifer distributed in the middle and downstream of the Zhangye Basin, which consists of cobble, medium and fine grained sand and clay. The hydraulic conductivity of the unconfined-confined aquifer varies from $5-25 \mathrm{~m} / \mathrm{d}$ approximately. The hydraulic gradient regulates groundwater flowing from the piedmont area of the Qilian Mountains to the northwestern corner of the basin. In piedmont area of the Qilian Mountains, there exists significant lateral groundwater recharge (Zhao et al., 2010).

\subsection{Mathematical model}

The three-dimensional groundwater flow of constant density through an aquifer can be written as (Eq. 1; Bear, 1979; Discacciati et al., 2002).

$$
\frac{\partial}{\partial x_{i}}\left(K_{i} \frac{\partial h}{\partial x_{i}}\right)+q_{s}=S_{s} \frac{\partial h}{\partial t} \cdot i=1,2,3 .
$$

Where $h$ is the hydraulic head (L); $K_{i}$ is the $\mathrm{i}^{\text {th }}$ principal component of the hydraulic conductivity sensor that coincides with the 1,2 or 3 coordinate axes $(\mathrm{L} / \mathrm{T})$; $q_{s}$ is the fluid sources/sink (/T); $S_{s}$ is the specific storage (/L); $t$ is time (T).

MODFLOW can be used to solve Eq. 1 by the finite-difference method.

The transport of a solute species in three-dimen- sional groundwater flow can be given by the advection-dispersion equation (Zheng and Bennett, 2002).

$$
\begin{gathered}
\frac{\partial(\theta C)}{\partial t}=\frac{\partial}{\partial x_{i}}\left(\theta D_{i j} \frac{\partial C}{\partial x_{j}}\right)-\frac{\partial}{\partial x_{i}}\left(q_{i} C\right)+q_{s} C_{s}+\sum R_{k}, \\
i, j=1,2,3 .
\end{gathered}
$$

Where $C$ is the solute concentration $\left(\mathrm{M} / \mathrm{L}^{3}\right) ; \theta$ is the effective porosity; $D_{i j}$ is the hydrodynamic dispersion tensor $\left(\mathrm{L}^{2} / \mathrm{T}\right) ; q_{i}$ is the $\mathrm{i}^{\text {th }}$ component of the specific discharge or Darcy flux in the 1,2, or 3 coordinate axes $(/ \mathrm{T}) ; C_{s}$ is the concentration in a fluid source/sink $\left(\mathrm{M} / \mathrm{L}^{3}\right) ; \sum R_{k}$ is the chemical reaction term $(/ \mathrm{T})$. MT3DMS can be perfectly solved by Eq. 2 .

The mean age of groundwater was derived by Goode (1996) as:

$$
\frac{\partial A}{\partial t}=\frac{\partial}{\partial x_{i}}\left(D_{i j} \frac{\partial A}{\partial x_{j}}\right)-\frac{\partial}{\partial x_{i}}\left(\frac{q_{i}}{\theta} A\right)+1, i, j=1,2,3 .
$$

Where $A$ is the mean groundwater age, also referred to as the mean residence time. Equation 3 is mathematically identical to Eq. 2. Thus the MT3DMS code developed for solute transport modeling can be used directly for groundwater age simulation. While groundwater age has traditionally been estimated by groundwater travel time of advection alone, the age model simulated by MT3DMS integrated the effects of dispersion, diffusion and mixing over the flow path. This simulation will help to get more accurate groundwater age. 


\subsection{Model construction}

The model domain is divided into 111 columns and 78 rows with each cell measuring $2 \mathrm{~km} \times 2 \mathrm{~km}$ size. The model covered an area of approximately $5,476 \mathrm{~km}^{2}$. According to drilling data and hydro geologic maps, the aquifer system is generalized by five layers: one unconfined aquifer, two confined aquifers and two aquitards.

The groundwater flow field is the basis of the solute transport model. Therefore the groundwater flow model was constructed in first. As the whole groundwater cycle process usually takes thousands of years, the steady-state flow was selected for this study. Ground elevation was generated from the $200 \mathrm{~m} \times 200$ m DEM (Digital Elevation Model). The initial hydraulic conductivity, specific yield, depth of each layer, were conceptualized from the hydro geologic report, pumping test and drilling data compiled by the Bureau of Geology and Mineral Resources of Gansu Province Hydrogeology and Engineering Geology Team. Hydraulic conductivity was regarded as horizontal isotropic.

The period of 1994-2004 was chosen as the simulation period. Each time step is 30 days, and the whole simulation period of 3,650 days were divided into 122 steps. The boundary conditions were generalized from hydro-geologic report and imported into MODFLOW 2000 groundwater flow module. Groundwater levels in April 2004 were interpolated by Kriging method and set as the initial water level. The actual groundwater age was calibrated by ${ }^{14} \mathrm{C}$ dating method, which determined the age by measuring the unit of percent modern carbon. ${ }^{14} \mathrm{C}$ dating was conducted in Mar 2009-June 2009 using reactive equipment designed by the Institute of Hydrogeology and Environmental Geology, Chinese Academy of Geological Sciences (IHEG, CAGS). The percent modern carbon was measured in the way of liquid scintillation counting after conversion to benzene by Liquid Scintillation Spectrometer (QUANTULUS, USA) in IHEG, CAGS.

\subsubsection{Conceptualization of sources and sinks}

The primary recharge is from irrigation and river leakage, lateral inflow from Qilian boundary and pre- cipitation. Discharge is composed of evapotranspiration, artificial groundwater exploitation and recharge to the river, among which evapotranspiration and artificial groundwater exploitation are major parts.

\subsubsection{Bottom and roof boundary generalization}

The Tertiary bedrock is beneath the deep aquifer of Zhangye Basin. According to the weak permeability or impermeability character of the Tertiary bedrock, it was regarded as the bottom boundary of the studied groundwater system. The atmosphere-soil interface is the roof boundary.

\subsubsection{Generalization of lateral boundaries}

The boundary around the model domain is regarded as the second type boundary in this study. According to the hydro-geologic report, there exists abundant lateral recharge from Qilian Mountains piedmont to groundwater system in the south of the basin (C-D in Fig. 1). In some other specified parts of the boundary $(\mathrm{A}-\mathrm{B}$, E-F and G-H in Fig. 1), the groundwater system receives the recharge in the form of deep seepage and valley underflow. So these parts were regarded as non-zero flow boundary. The recharge was calculated from the hydro-geologic report and imported to the groundwater flow module. In other parts of study area, on account of little rainfall and fractured water in rocks, the boundary conditions were regarded zero flow boundaries.

\subsubsection{Generalization of boundaries in solute trans- port model}

A zero flow boundary in the flow model is assigned as a no concentration flux i.e. no age flux boundary in the age transport model. An inflow boundary is specified as a no concentration flux boundary since the age of entering inflow is considered zero. An outflow boundary is allowed to carry solute concentrations freely out of the model domain.

\subsection{Model calibration}

The groundwater flow model was calibrated by observed well data from West Data Center, National Natural Science Foundation of China. The calibrated parameters are shown in Fig. 2 and Table 1. Comparison between observed and simulated hydraulic heads is shown in Figs. 3 and 4. The mean residual is 0.300 $\mathrm{m}$ in total 33 observation wells. The mean absolute 
Table 1 Hydraulic parameters in groundwater flow model

\begin{tabular}{|c|c|c|c|c|}
\hline Subarea & Layer & $\begin{array}{l}\text { Horizontal hydraulic conductivity } \\
(\mathrm{m} / \mathrm{s})\end{array}$ & $\begin{array}{l}\text { Vertical hydraulic conductivity } \\
(\mathrm{m} / \mathrm{s})\end{array}$ & Specific yield \\
\hline \multirow{3}{*}{1} & 1 & 7.34E-05 & 7.22E-06 & 0.11 \\
\hline & 2,4 & $1.00 \mathrm{E}-06$ & $1.00 \mathrm{E}-07$ & 0.03 \\
\hline & 3,5 & $5.36 \mathrm{E}-05$ & $6.22 \mathrm{E}-06$ & 0.09 \\
\hline \multirow{4}{*}{2} & 1 & $1.06 \mathrm{E}-04$ & $2.04 \mathrm{E}-05$ & 0.13 \\
\hline & 2,4 & $1.00 \mathrm{E}-06$ & $1.00 \mathrm{E}-07$ & 0.03 \\
\hline & 3 & $1.01 \mathrm{E}-04$ & $1.72 \mathrm{E}-05$ & 0.11 \\
\hline & 5 & 2.19E-04 & $2.25 \mathrm{E}-05$ & 0.21 \\
\hline \multirow{2}{*}{3} & $1,3,5$ & $1.53 \mathrm{E}-04$ & $2.12 \mathrm{E}-05$ & 0.14 \\
\hline & 2,4 & $1.00 \mathrm{E}-06$ & $1.00 \mathrm{E}-07$ & 0.03 \\
\hline \multirow{2}{*}{4} & $1,3,5$ & $1.77 \mathrm{E}-04$ & $2.39 \mathrm{E}-05$ & 0.16 \\
\hline & 2,4 & $1.00 \mathrm{E}-06$ & $1.00 \mathrm{E}-07$ & 0.03 \\
\hline \multirow{4}{*}{5} & 1 & $2.67 \mathrm{E}-04$ & 3.32E-05 & 0.21 \\
\hline & 2,4 & $1.00 \mathrm{E}-06$ & $1.00 \mathrm{E}-07$ & 0.03 \\
\hline & 3 & 2.12E-04 & $3.56 \mathrm{E}-05$ & 0.19 \\
\hline & 5 & $2.28 \mathrm{E}-04$ & $4.25 \mathrm{E}-05$ & 0.19 \\
\hline \multirow{3}{*}{6} & 1 & $9.71 \mathrm{E}-05$ & 7.24E-06 & 0.17 \\
\hline & 2,4 & $1.00 \mathrm{E}-06$ & $1.00 \mathrm{E}-07$ & 0.03 \\
\hline & 3,5 & $6.15 \mathrm{E}-05$ & 4.25E-06 & 0.13 \\
\hline \multirow{3}{*}{7} & 1 & 7.74E-05 & $6.76 \mathrm{E}-06$ & 0.16 \\
\hline & 2,4 & $1.00 \mathrm{E}-06$ & $1.00 \mathrm{E}-07$ & 0.03 \\
\hline & 3,5 & 5.32E-05 & $5.65 \mathrm{E}-06$ & 0.15 \\
\hline \multirow{3}{*}{8} & 1 & $2.69 \mathrm{E}-04$ & $3.76 \mathrm{E}-05$ & 0.22 \\
\hline & 2,4 & $1.00 \mathrm{E}-06$ & $1.00 \mathrm{E}-07$ & 0.03 \\
\hline & 3,5 & $2.19 \mathrm{E}-04$ & $2.25 \mathrm{E}-05$ & 0.21 \\
\hline 9 & $1-5$ & 5.93E-04 & 7.65E-05 & 0.29 \\
\hline 10 & $1-5$ & $5.24 \mathrm{E}-04$ & $6.77 \mathrm{E}-05$ & 0.27 \\
\hline 11 & $1-5$ & 4.64E-04 & $4.35 \mathrm{E}-05$ & 0.25 \\
\hline 12 & $1-5$ & 4.91E-04 & $5.72 \mathrm{E}-04$ & 0.26 \\
\hline
\end{tabular}

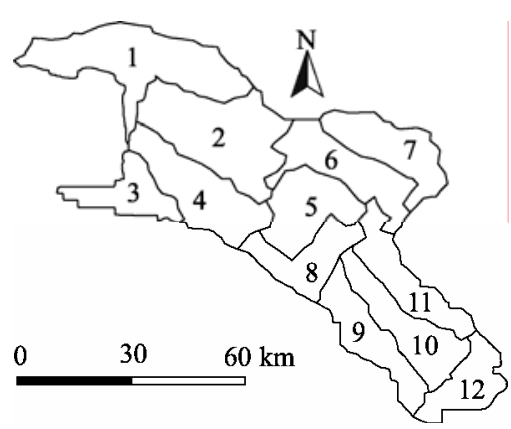

Fig. 2 The subareas for hydraulic parameter in study area

error is $0.939 \mathrm{~m}$, the standard error of the estimate is $0.191 \mathrm{~m}$ with a maximum residual $2.684 \mathrm{~m}$ and a minimum residual $0.045 \mathrm{~m}$. The frequency and residuals obey a normal distribution. In addition, all simulated hydraulic parameters were situated in a 5\% reasonable range. According to calibration results above, we ensured the flow model created a good match to the actual groundwater flow system in the study area.

In solute transport part of age simulation, parameters adjusted were longitudinal dispersivity $\alpha_{L}$, the ratio of transverse to longitudinal dispersivity $\alpha_{\mathrm{T}} / \alpha_{\mathrm{L}}$, the ratio of vertical to longitudinal dispersivity $\alpha_{V} / \alpha_{L}$. These parameters were adjusted as $\alpha_{L}=10 \mathrm{~m}$, $\alpha_{\mathrm{T}} / \alpha_{\mathrm{L}}=0.1$ and $\alpha_{\mathrm{V}} / \alpha_{\mathrm{L}}=0.01$. Observed groundwater age was measured in the ${ }^{14} \mathrm{C}$ isotope method. Four groundwater samples were collected to determine groundwater age for model calibration. Sampling site 
was shown in Fig. 5. The samples were collected from agricultural pumping well with the maximum depth of $110 \mathrm{~m}$ approximately. As most unconfined aquifer (the first layer aquifer) is deeper than $110 \mathrm{~m}$, these samples can represent the properties of unconfined aquifer. Age simulation results were shown in Table 2 (the simulated value is from unconfined aquifer accordingly). The solute transport model is reasonable and accepted considering all simulated age error $<7 \%$ compared to measured samples with a minimum residual of $1.50 \%$. Then the simulated groundwater age result is regarded reliable.

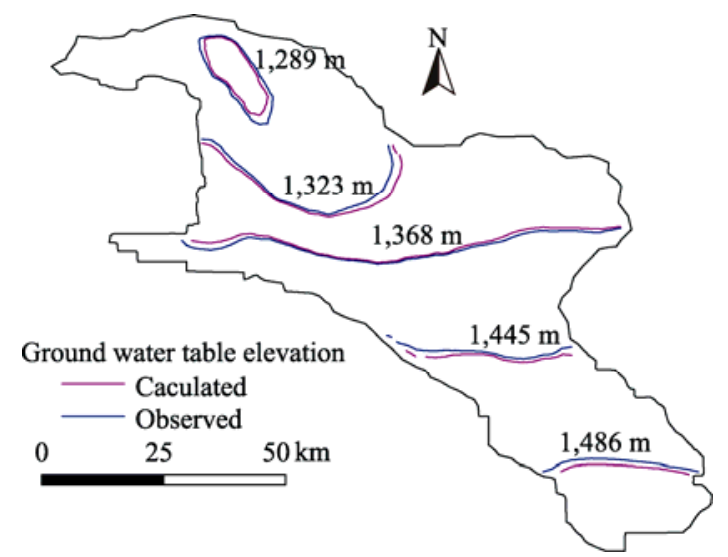

Fig. 3 Simulated ground water table elevations versus observed values in study area

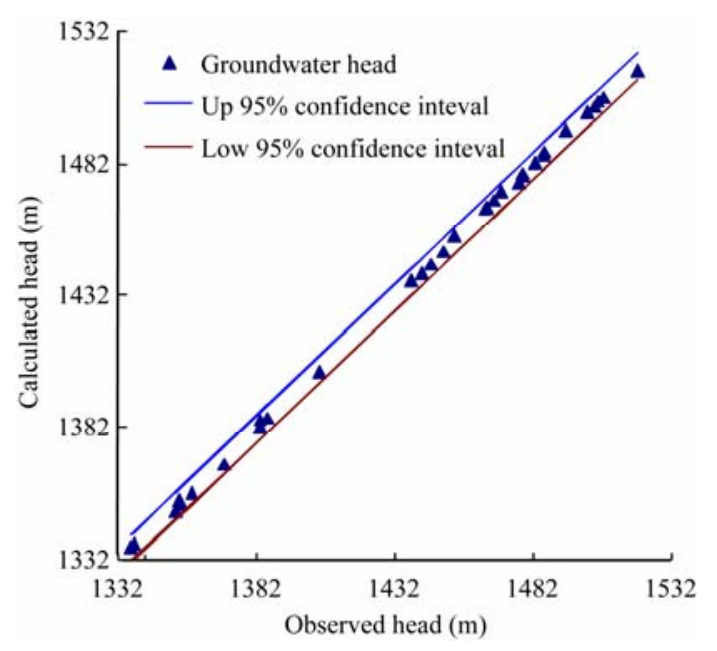

Fig. 4 Simulated versus observed hydraulic heads

Table 2 Simulated ages versus carbon-14 dating values

\begin{tabular}{lcccc}
\hline & $1 \#$ & $2 \#$ & $3 \#$ & $4 \#$ \\
\hline Simulated value $(\mathrm{ka})$ & 4.38 & 5.23 & 3.51 & 4.57 \\
Measured value $(\mathrm{ka})$ & 4.23 & 5.31 & 3.74 & 4.72 \\
\hline
\end{tabular}

\section{Results and discussion}

The groundwater age calculation result is shown in Fig. 5. The age distribution of the unconfined aquifer is shown in Fig. 5a. As shown the youngest groundwater in the basin was less than 1,000 a, which was located in the most upstream area. The groundwater age of the middle area is older than the upstream area. In this area, age in the western part of this region $(2,000 \mathrm{a}-4,000 \mathrm{a})$ is younger than eastern part $(4,000$ a-6,000 a). The oldest groundwater is located in the most downstream of the basin (the northwest end), which is older than 6,000 a, even some place can exceed 10,000 a. Figure $5 \mathrm{~b}$ shows the age distribution of the first confined aquifer. In the downstream of the basin, groundwater age in the first confined aquifer is a little older than the unconfined aquifer with more cells over 12,000 a. In the second confined aquifer, also the deepest aquifer in this study, the age distribution is shown in Fig. 5c. Compared to the first confined aquifer, the age is older in east and west edges of the middle area of the basin. The obvious difference in the second confined aquifer is in the downstream area, where the groundwater is relatively old with the age nearly all cells over 12,000 a and in some places more than 20,000 a. Generally, the groundwater age in the study area distributed in the pattern: upstream $<$ midstream $<$ downstream horizontally and unconfined aquifer $<$ the first confined aquifer $<$ the second confined aquifer vertically, which is similar to the hydrological process of surface water.

Due to the fine permeability of the gravel aquifer in the most upstream area, the Heihe River water infiltrates in large quantity when it flows through the outlet of Qilian Mountains. The groundwater system gets abundant recharge in this process and the youngest groundwater in the aquifer forms. However, in the southeast end of the basin, and in the upstream area, groundwater age ranges from 1,000 to 2,000 a, which is older than the youngest area. This difference indicates the importance of river leakage to the unconfined aquifer recharge process (Ding et al., 2006). In middle area of the Zhangye Basin, the Heihe River flows through the western part and sustains vast oasis (Fig. 6), this close hydraulic connection from 
(a)

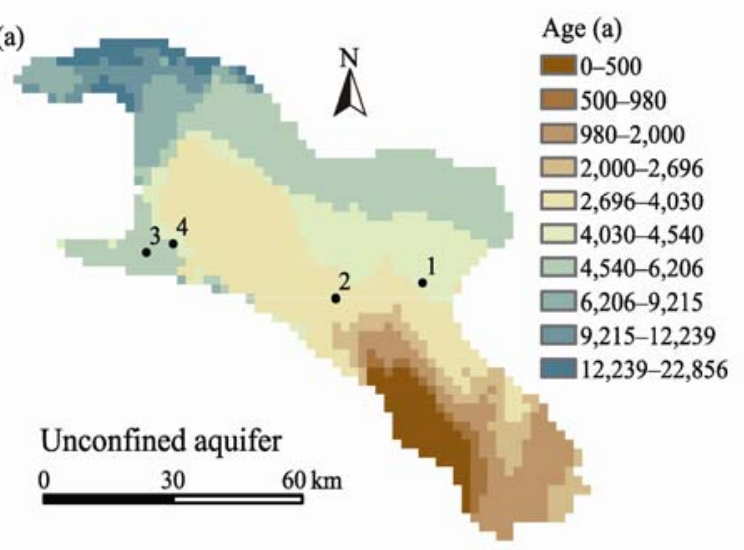

(b)

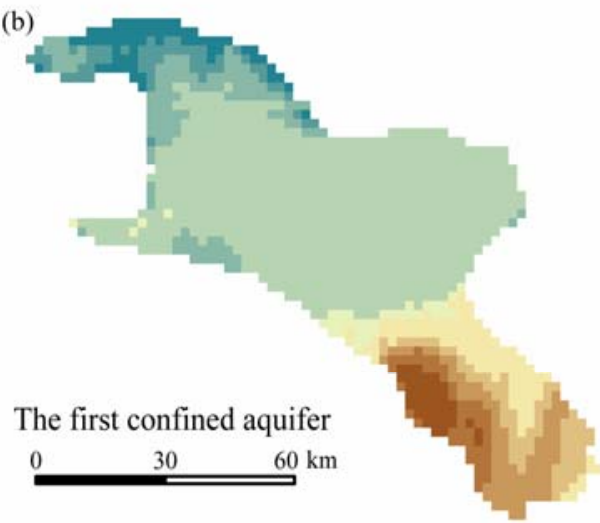

(c)

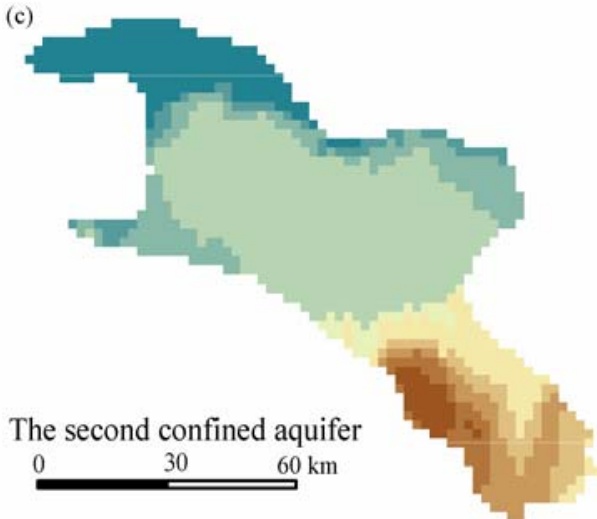

Fig. 5 Distribution of groundwater age in the study area

surface water brings the aquifer fine renewal capacity and represents a relatively younger age. The eastern part of this area is far away from the river and oasis with little rainfall and a landscape of bare desert or mountain. The extremely limited recharge availability weakens the renewal capacity and results in an older groundwater age in this area. For these different recharge processes, younger groundwater age of western to the eastern part in middle area of the basin became reasonable. Besides the long traveling process and slow flowing caused by the low hydraulic gradient (Todd and Mays, 2004), the groundwater age is also impacted by different recharge processes. There also exist evident groundwater age differences in the middle area of the basin between confined and the unconfined aquifers. In the unconfined aquifer the age of western part is younger than east, but in the first confined aquifer the age is approximately uniform. This result indicates the different recharge source between two aquifers (Mohammad and William, 2012). The unconfined aquifer is mainly charged by surface water and therefore the groundwater age is affected by issues such as distance to river and land use types, while groundwater in the first confined aquifer is recharged mainly through groundwater flow and therefore shows a relatively uniform age distribution.

Most hydrologists hold the view that groundwater flow and the age are mainly affected by the hydro geologic conditions such as the hydraulic gradient and conductivity (Fetter, 2000; Vissers and Vander, 2008; Xie et al., 2013), but based on the simulated result in this study, we can conclude that in the semi-arid inland areas, the hydraulic connection to the surface

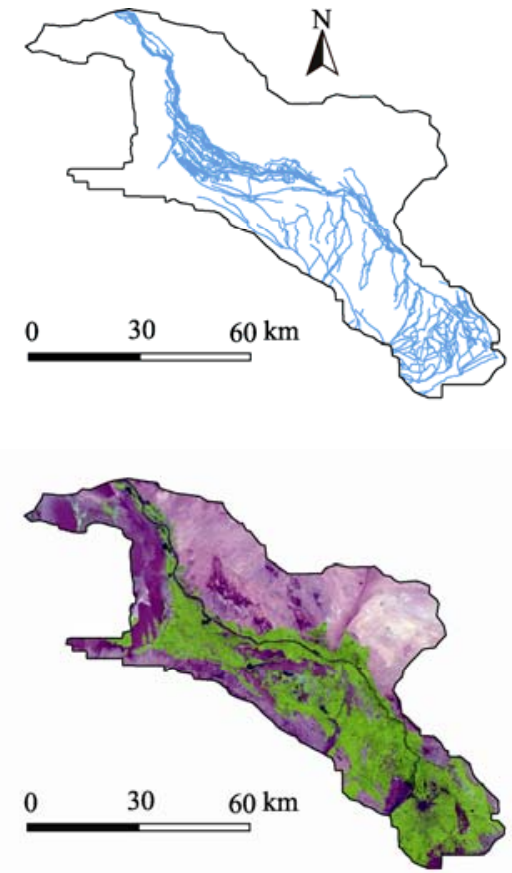

Fig. 6 River \& canal systems and land use types in the study area 
water may play a more important role than expected one. On the other hand, based on the relationship between the groundwater age and the water resource sustainability (Xia et al., 2004; Molson and Frind, 2012), the simulated results show that the groundwater resources in downstream areas would take a rather long time to be formed. Thus it may be more restrained in groundwater exploitation activity in these areas.

\section{Conclusions}

We simulated groundwater age by combining the groundwater flow and transport models in a regional sedimentary basin in this study. The simulation results show that the groundwater resources in downstream areas would take a rather long time to be formed, which indicates a low renewal capacity and sustainability. On the other hand, based on the analysis of the groundwater age distribution, we concluded that the hydraulic connection to the surface water may play a more important role than expected one in affecting groundwater flow and the age in the semi-arid inland areas.

However, groundwater flow in a regional scale is a complex system. According to the complicated geological condition, we should conduct more hydrogeological survey to improve the three-dimensional flow model. Additional ${ }^{14} \mathrm{C}$ dating samples should be collected and other isotopic dating methods should be applied for more precise calibration to groundwater age.

\section{Acknowledgements}

This work was financially supported by the National Natural Science Foundation of China (91225301). The authors have also benefited from communications from Dr. GuoLiang CAO and Cheng YU in numerical models. The authors would give great thanks to the reviewers and editors for their good comments and revisal suggestions.

\section{References}

Anderson M P, Woessner W W. 1992. Applied Groundwater Modeling: Simulation of Flow and Advective Transport. San Diego: Academic Press Inc, 22-35.
Bear J. 1979. Hydraulics of Groundwater. New York. McGraw-Hill, $12-40$.

Chen X, Yan J F, Chen Z, et al. 2009. A spatial geostatistical analysis of impact of land use development on groundwater resources in the Sangong Oasis Region using remote sensing imagery and data. Journal of Arid Land, 1(1): 1-8.

Chen Y N, Xu C C, Chen Y P, et al. 2013. Progress, challenges and prospects of eco-hydrological studies in the Tarim river basin of Xinjiang, China. Environmental Management, 51(1): 138-153.

Dafny E, Burg A, Gvirtzman H. 2010. Effects of Karst and geological structure on groundwater flow: the case of Yarqon-Taninim Aquifer, Israel. Journal of Hydrology, 389(3-4): 260-275.

Ding H W, Zhang J. 2002. The problem of environmental caused by groundwater level continuous decline in the inland basins of arid area, Northwest China-an example in middle reaches of Heihe river basin. Hydrogeology and Engineering Geology, 3: 71-75.

Ding H W, Zhang J, Lu Z, et al. 2006. Characteristics and cycle conversion of water resources in the Hexi corridor. Arid Zone Research, 23(2): 241-248.

Discacciati M, Migliob E, Quarteroni A. 2002. Mathematical and numerical models for coupling surface and groundwater flows. Applied Numerical Mathematics, 43(1-2):57-74.

Feng Q, Cheng G D, Endo K H. 2002. Towards sustainable development of the environmentally degraded river Heihe Basin, China. Hydrological Science Journal, 46(5): 647-658.

Fetter C W. 2000. Applied Hydrogeology, $4^{\text {th }}$ ed. New York: Prentice Hall, 123-152.

Gleeson T, Vander S J, Sophocleous M, et al. 2010. Groundwater sustainability strategies. Nature Geoscience, 6(3): 378-379.

Goode D J. 1996. Direct simulation of groundwater age. Water Resources Research, 32(2): 289-296.

Lu L, Li X, Cheng G D. 2003. Landscape evolution in the middle Heihe River Basin of north-west China during the last decade. Journal of Arid Environments, 53(3): 395-408.

Luo Y, Sophocleous M. 2011. Two-way coupling of unsaturated-saturated flow by integrating the SWAT and MODFLOW models with application in an irrigation district in arid region of West China. Journal of Arid Land, 3(3): 164-173.

Ma L, Wei X M, Bao A M, et al. 2012. Simulation of groundwater table dynamics based on Feflow in the Minqin Basin, China. Journal of Arid Land, 4(2): 123-131.

Mohammad A H, William G B. 2012. ${ }^{14} \mathrm{C}$ dating of deep groundwater in the Bengal Aquifer System, Bangladesh: Implications for aquifer anisotropy recharge sources and sustainability. Journal of Hydrology, 444-445(11): 209-220.

Molson J W, Frind E O. 2012. On the use of mean groundwater age, life expectancy and capture probability for defining aquifer vulnerability and time-of-travel zones for source water protection. Journal of Contaminant Hydrology, 127(1-4): 76-87. 
Peleg N, Gvirtzman H. 2010. Groundwater flow modeling of two-levels perched Karstic leaking aquifers as a tool for estimating recharge and hydraulic parameters. Journal of Hydrology, 388(1-2): 13-27.

Qian Y B, Fan Z L, Lei J Q, et al. 2006. Exploitation of water and land resources and its ecoenvironment issues in Xinjiang of China in resent 50 a. Journal of Arid Land Resources and Environment, 20(3): 58-63.

Sophocleous M A, Perkins S P. 2000. Methodology and application of combined watershed and ground-water models in Kansas. Journal of Hydrology, 236(3-4): 185-201.

Todd D K, Mays L W. 2004. Groundwater Hydrology, $2^{\text {nd }}$ ed. New York: Wiley, 33-76.

Vincent E A, Alexander V, Adrian D W, et al. 2013. Groundwater ages in coastal aquifers. Advances in Water Resources, 57: 1-11.

Vissers M J, Vander P M. 2008. The stability of groundwater flow systems in unconfined sandy aquifers in the Netherlands. Journal of Hydrology, 348(3-4): 292-304.

Wang G X, Liu J Q, Jumpei K, et al. 2007. Effects of land-use changes on hydrological processes in the middle basin of the Heihe River, northwest China. Hydrological Processes, 21(10): 1370-1382.

Wen X H, Wu Y Q, Lee L J, et al. 2007. Groundwater flow modeling in the Zhangye Basin, Northwestern China. Environmental Geology,
53(1): 77-84.

Wilson Y F, Hiroshi S, Festus T A, et al. 2010. Hydrochemical and isotopic evidence of recharge, apparent age, and flow direction of groundwater in Mayo Tsanaga River Basin, Cameroon: bearings on contamination. Environmental Earth Sciences, 60(1): 107-120.

Xi H Y, Feng Q, Liu W, et al. 2010. The research of groundwater flow model in Ejina Basin, Northwestern China. Environmental Earth Sciences, 60(5): 953-963.

Xia J, Wang Z G, Wang G S, et al. 2004. The renewability of water resources and its quantification in the Yellow River basin, China. Hydrological Processes, 18(12): 2327-2336.

Xie X J, Wang Y X, Ellis A, et al. 2013. Delineation of groundwater flow paths using hydro chemical and strontium isotope composition: a case study in high arsenic aquifer systems of the Datong basin, northern China. Journal of Hydrology, 476(7): 87-96.

Zhao C Y, Wang Y C, Chen X, et al. 2005. Simulation of the effects of groundwater level on vegetation change by combining FEFLOW software. Ecological Modelling, 187(2-3): 341-351.

Zhao J Z, Wei L L, Zhao Y P, et al. 2010. Surface water and groundwater transformation research in Heihe River Basin. Northwestern Geology, 43(3): 120-126.

Zheng C M, Bennett G D, 2002. Applied Contaminant Transport Modeling, $2^{\text {nd }}$ ed. New York: Wiley, 63-76. 